\title{
TSC1 Gene Rearrangement
}

National Cancer Institute

\section{Source}

National Cancer Institute. TSC1 Gene Rearrangement. NCI Thesaurus. Code C153525.

A molecular abnormality indicating rearrangement of the TSC1 gene. 